\title{
Antioxidant Therapy: Myth or Reality?
}

\author{
Alberto J. Núñez-Sellés \\ Center of Pharmaceutical Chemistry, Ave 21 \& 200, Atabey, Apdo 16042, CP 11600, Havana, Cuba
}

\begin{abstract}
Termos novos, tais como stress oxidativo, produtos anti-oxidantes ou risco pro-oxidante, estão se tornando mais comuns, e o aumento no número de conferências científicas internacionais e a publicação de milhares de artigos científicos é uma indicação do crescente interesse no assunto. $\mathrm{O}$ exemplo mais conhecido é o Paradoxo Francês, baseado na aparente compatibilidade de uma dieta rica em gordura com a baixa incidência de arteriosclerose coronária atribuída ao consumo regular, pelos franceses, de vinho tinto ou suco de uva. Flavonoides, e outras substâncias fenólicas encontradas no vinho tinto, são indicadas como anti-oxidantes, o que diminui a oxidação de lipoproteínas de baixa densidade, conseqüentemente diminuindo o risco de doenças artereogenicas. Outros exemplos são, o processo de envelhecimento e sua correlação com o aumento de radicais livres, e a relação entre início e promoção do câncer e alteração nos tecidos provocadas por radicais livres, o que induz a ingestão de produtos anti-oxidantes como um fator químico que previna a instalação de doenças. Atualmente, a incidência do stress oxidativo na aquisição e progresso de mais de 100 doenças tem sido sugerida por diversos cientistas. Todas essas "evidências reais", que por outro lado não possuem maiores evidências clínicas, são consideradas tanto por médicos como por organismos reguladores da saúde, como "mitos" ou de importância "secundária". Numa tentativa de destruir tais mitos, resultados de pesquisas químicas, pré-clínicas e trabalhos clínicos com o estrato puro das cascas de tronco de mangueira (Mangifera indica L.), desenvolvida em Cuba, foram revistos, com fortes evidências experimentais de suas propriedades antioxidantes, antiinflamatórias e imunomodulatórias.
\end{abstract}

New terms such as oxidative stress, antioxidant products or pro-oxidant risks are becoming familiar and an increasing number of international scientific conferences and the publication of thousands of scientific articles is an indication of the growing interest that the subject awakens. The most publicized example is perhaps the French paradox, based on the apparent compatibility of a high fat diet with a low incidence of coronary atherosclerosis attributed to the regular consumption, by the French, of red wine and/or grape juice. Flavonoids, and other phenolic substances contained in red wine, are assigned with antioxidant properties, which lower the oxidation of low density lipoproteins and consequently, the risk of atherogenic diseases. Other examples are the aging process and its correlation with an increase of free radicals, and the correlation between the initiation and promotion of cancer and tissue injury by free radicals, which has induced the intake of antioxidant products as chemical factors that prevent the onset of the disease. Currently, the incidence of oxidative stress on the onset and evolution of more than 100 diseases is claimed by several researchers. All these are "realities", which on the other hand, are lacking of more clinical evidence, are considered by both physicians and health regulatory bodies, either as "myths" or of "secondary" importance. In the attempts to destroy those myths, results of chemical, preclinical, and clinical works with a crude extract of mango (Mangifera indica L.) stem bark, which has been developed in Cuba, are reviewed, with a strong experimental evidence of its antioxidant, antiinflammatory and immunomodulatory properties.

Keywords: Mangifera indica L., volatile and non-volatile components, elemental quantitative analysis, antioxidant activity, anti-inflammatory activity, analgesic activity, immunomodulatory activity, clinical trial

\section{Introduction}

Flavonoids and other phenolic substances have become familiar since an European epidemiological study on

*e-mail: alberto@cqf.co.cu cardiovascular diseases risks was conducted in the 80's, leading to the phrase known as "The French Paradox", ${ }^{1}$ based on the apparent compatibility of a high fat diet with a low incidence of coronary atherosclerosis attributed to the regular consumption, by the French, of red wine and/or grape juice, 
both with a high flavonoid content. ${ }^{2}$ Flavonoids, and other phenolic substances contained in red wine, are assigned with antioxidant properties, ${ }^{3}$ which lower the oxidation of low density lipoproteins (LDL) and consequently, the risk of atherogenic diseases. ${ }^{4,5}$ Other examples are the correlation observed between the aging process of the human body and the increase of free radicals due to the drop in the oxygen used by metabolic processes, ${ }^{6}$ and the initiation and promotion of cancer and tissue injury by free radicals, ${ }^{7-10}$ which has induced the intake of antioxidant products as chemical factors that prevent the onset of the disease. Cell degradation processes may lead to a partial or total loss of the functions of the physiological systems of the body. Currently, the incidence of free radical imbalance on the onset and evolution of more than 100 diseases (cardiovascular, neurological, endocrine, respiratory, immune and self-immune, ischaemia, gastric disorders, tumor progression and carcinogenesis, among others) has been demonstrated. ${ }^{11-17}$ However, the relationship between oxidative stress and the progression of diseases has not attracted the attention of the scientific and medical communities until recent years. Most of the physicians have considered the "antioxidant therapy" of secondary importance or not relevant for therapeutics. One of the contributing factors to that situation is the regulatory environment, where antioxidants can not be considered as drugs but food or dietary supplements, because the oxidative stress has not been described as a syndrome and it is not a pharmacological or physiological disorder. Marketers have taken advantage of that situation (there is not need of clinical trials!) and new terms for antioxidants and other natural products as well have appeared as nutraceuticals (nutritional supplements with pharmaceutical applications), functional foods (foods with one or more additives with therapeutical effects), cosmeceuticals (cosmetics which may improve skin health), and natural health products (natural products with claimed but not proved therapeutical effects). Promotion and publicity have attributed to these products therapeutical properties, sometimes miraculous (the myth), which are not supported on a strong scientific evidence (the reality), from companies more interested on profits and sales than health improvement.

Perhaps, the largest myth of the oxidative stress is the claim of nutritionists and natural products researchers, in hundreds of publications, that is related to more than 100 diseases, and a lot of oxidative stress markers in biological fluids have been described. Medical authorities are reluctant to that claim and ask for long-term randomized double-blind clinical trials on thousands of people to assure the effectiveness of antioxidant therapy for a specific medical application. These are the extremes of the present situation about antioxidant therapy.
Nevertheless, the reality is the increasing number of controlled clinical trials which are demonstrating the relevance of the antioxidant therapy in diseases. Supplementation with vitamin C (1,000 mg/day) and vitamin E (400 IU/day) has reduced the incidence of preeclampsia in women at risk and this was associated with improvement in a range of biochemical markers of placental insufficiency and oxidative stress supporting the rationale of prophylactic use of antioxidants. ${ }^{18}$ Other studies revealed that antioxidant protection on bone and cartilage may not work directly on the damaged tissue by oxidative chemical species (OCS) but may instead shift cytokine balance, like glycoaminoglucans, carotenoids, essential fatty acids and flavonoids. ${ }^{19}$ Oral supplementation with glucosamine sulfate has been examined in osteoarthritis and subjects reported a significant reduction in pain and decrease limitations on active and passive movements than all other treatments. ${ }^{20}$ A clinical trial on the effect of chronic administration of vitamin E (600 IU/day) on the cardiac autonomic nervous system was investigated over a period of 4 months in 50 type-2 diabetic patients with neuropathy. Vitamin E significantly improved measures of diabetes (glycated hemoglobin and plasma insulin), oxidative stress (catechol amines) and hearth functions. ${ }^{21}$ The effect of a high dose of vitamin A (25,000 IU) and vitamin E (500 IU) supplementation on corneal re-epitelization time, visual acuity and haze using two groups of 20 patients (treated and placebo) who underwent photorefractive keratectomy was studied in a 1-year trial. Patients supplemented with vitamins $\mathrm{A}+\mathrm{E}$ were significantly improved $(\mathrm{p}<0.05)$ as compared to the placebo group suggesting that antioxidant therapy may accelerate the healing process in these patients. $^{22}$

The reality has overpass the myth, but it is not enough. Many natural products, asumed to have strong antioxidant properties, with a large ethnomedical and historical practice in Latin America and other economical non-developed countries, are lacking funds for adequate scientific and clinical research. No less important is the practice of most research groups and pharmaceutical companies from the West World to consider only valid a single-purified compound from a natural product extract better than a standardized whole-crude natural extract with a large number of components to be developed as a new product for therapeutics. Asian medicine and its millenary practice have demonstrated the contrary.

We present in this review, for the first time, the compilation of most relevant scientific articles and technical reports of the chemical, pre-clinical, and clinical research on the standardized whole-crude extract of mango 
stem bark (Mangifera indica L., Anacardiaceae) with antioxidant, anti-inflamatory, and immunomodulatory properties, which has been developed in Cuba as nutritional supplement or functional food in several formulations (antioxidant), or anti-inflamatory, analgesic and immunomodulator (tablet, capsule, syrup, and cream) to prevent disease progress or the patient's quality of life in diseases like HIV/AIDS, cancer, asthma, gastric and dermatological disorders, etc. Just an example of how the myth can be changed to a reality.

\section{Ethnomedical Knowledge of Mango (Mangifera indica L.) Extracts}

Mango extracts from leaves, fruit seed kernel, fruit pulp, roots, bark, and stem bark for medicinal purposes in many countries have been extensively reported in the Napralert Data Base. ${ }^{23}$ Specifically, the ethnomedical use of the mango stem bark aqueous extract (MSB) in Cuba has been documented widely ${ }^{24}$ and it has been extensively used in cancer, diabetes, asthma, infertility, lupus, prostatitis, prostatic hyperplasia, gastric disorders, arthralgies, mouth sores, and tooth pain, as the more frequent diseases. Non-documented verbal references from old cuban people told about uses of the MSB by African slaves in Cuba since the XIX century. A documented data from more than 7 thousand patients with 84 diseases have been compiled in Cuba during the last 10 years. Focal studies have been done on specific diseases of relevant importance like cancer ${ }^{25}$ in order to evaluate disease progress and the improvement of the patient's quality of life in a six-months field trial. $84.8 \%$ of patients diminished a high depression, $82.2 \%$ of patients had a better integral evaluation, and $89.7 \%$ of them were able to have a normal life with an average dose of $20 \mathrm{mg} / \mathrm{kg}$ body weight (b. w.) after oral administration $(30 \mathrm{~mL})$ three times a day of an aqueous decoction of MSB.

Above described results were considered as a ground basis for the development of a new product from the MSB with the hypothesis that so many successful applications would be only sustained from its antioxidant effect better than a specific medical application. Therefore, the MSB was developed up to the industrial scale, standardized, and formulated to be used as an antioxidant nutritional supplement, a cosmeceutical product, and phytomedicine strongrelated to oxidative stress (pain and inflammation), ${ }^{26}$ with an adequate protection of the intellectual property by a patent ${ }^{27}$ and registered brand name (Vimang).

\section{Oxidative Stress}

Oxidative stress is the imbalance between the generation of OCS and the body defense mechanisms (preventive, scavenger, and reparative). OCS in excess may be originated in the organism by defects in mytochondrial respiration, activation of nuclear polymorphs, arachydonic acid metabolism, activation-inhibition of enzyme systems, and iron- or copper-related catalysis (endogenous factors) ${ }^{28}$ Environmental pollutants, toxic habits (drugs, smoke, and/or alcohol), inadequate nutrition, excess solar radiation, large exposure to toxic substances (fertilizers and pesticides i.e.), drug metabolism (side-effects), and a high physical or psychical stress are the most common exogenous factors originating OCS in the human organism. Another source is the alteration of cell functions on DNA, lipids, and carbohydrates, which generates nonreversible reactions and OCS like malonyl dialdehyde and organic hydroperoxides with a propagation of the oxidative damage.

The antioxidant body mechanisms against excess of OCS may be classified as follows: ${ }^{28}$

\subsection{Preventive mechanism}

Proteins which have a coordinated nucleus, like iron and copper, or with the capacity to bind those metals, like albumine, metallothioneine, cerulloplasmine (copper), and ferritine, transferrine, myoglobine (iron), prevent the production of hydroxyl radical.

\subsection{Repairing mechanism}

Enzymes which repair or eliminate damaged biomolecules by OCS like glutathione peroxidase (GP), glutathione reductase (GR), and methionine-sulphoxide reductase (MSR).

\subsection{Scavenger mechanism}

Enzymes with capacity to scavenger excesses of OCS like superoxide dismutase (SOD), GP, catalase, and other metalloenzymes, together with chemical entities with scavenging capacities like polyunsaturated fatty acids, vitamins (C and E), uric acid, billirubine, carotenoids, and flavonoids.

The best antioxidant product is that able to prevent the excess of OCS, stimulate the endogenous antioxidant repairing mechanism, and provide a large amount of chemical entities to increase the endogenous antioxidant scavenger mechanism. Fresh fruits and vegetables in the 
diet is the best way to prevent OCS excess. ${ }^{29}$ However, the continuous exposure to environmental and other risks, which are unavoidable by most of the people, would lead to an oxidative stress in a larger or lesser extent, but mainly present.

The relationship between oxidative stress and diseases might be well understood if it is considered the effect of an excess of OCS at the cellular level. A cell attacked by OCS may: ${ }^{30}$ (i) modify its gene expression by the modification of DNA structure and/or the destruction of base pairs; (ii) repress gene expression by the inhibition and/or destruction of transcriptional factors; (iii) loose its integrity by rupture of the cell wall by lipid oxidation; (iv) modify its functions by the accumulation of oxidized low-density lipoproteins (LDLs); (v) activate or inactivate key enzymes for cell function.

All or part of those cell degradation processes would influence physiological body systems, which support the correlation between oxidative stress and disease progress. Neurodegenerative disorders are among the most studied, although still it is not clear the cause of neuronal death. ${ }^{31}$ A recent report evidenced that the dysfunction of glutathione metabolism by the oxidative stress may be an important factor in the pathogenesis of Alzheimer's disease (AD). Strong evidence that oxidative stress is involved in the pathogenesis of $\mathrm{AD}$ comes from a clinical study showing that oral vitamin $\mathrm{E}$ intake delayed progression in patients with moderately severe impairment from AD. ${ }^{32}$ The role of oxidative stress in $\mathrm{AD}$ is further supported by increased levels of thiobarbituric acid-reactive substances and 4-hydroxynonenal. Recently, a new biomarker for AD in the silent phase of the disease characterized by mild cognitive impairment (MCI) has been reported as 8,12isoPGF $_{2 \alpha}-$ VI. MCI patients were found to have significantly higher levels of the isoprostanoid in cerebrospinal fluid, plasma and urine as compared to cognitively normal elderly subjects. ${ }^{33}$ Induced neurodegeneration in AD by the oxidative stress is reduced by a gene in a transgenic animal model, where neurone cellular replication was inhibited. ${ }^{34}$ Moderate oxidative stress may specifically inhibit several types of genes through the influence of OCS on transcriptional factors in the central nervous system. ${ }^{35}$

\section{Chemical Profile of Mango Stem Bark (MSB) Aqueous Extract}

The industrial scale MSB is obtained from selected cultivars grown in Cuba, free of microbial contamination (fungi) and chemical residues from fertilizers, fungicides or pesticides. ${ }^{36}$ It is dried by hot air $\left(50{ }^{\circ} \mathrm{C}, 2 \mathrm{~h}\right)$, milled (hammer mill), and extracted with water until a liquor (12\% solids content) is obtained. After liquor preservation, the water is evaporated by spray drying, leading to a homogeneous brown powder which melts with decomposition from $215{ }^{\circ} \mathrm{C}$ to $218{ }^{\circ} \mathrm{C}$ and has a particle size of $30-60 \mu \mathrm{m}$. That crude solid extract has been standardized at the industrial scale in terms of $\mathrm{pH}$, solubility, color (colorimetry), content of polyphenols (ultraviolet spectroscopy, UV), and content of mangiferin (high performance liquid chromatography, HPLC) for subsequent use as raw active principle in nutraceutical, cosmeceutical, and phytopharmaceutical formulations. ${ }^{37}$ Mangiferin, MF (1) is the major component in MSB as determined by HPLC and HPLC-Mass Spectrometry (HPLC-MS) and has been fully characterized by ${ }^{\mathrm{I}} \mathrm{H}$ and ${ }^{13} \mathrm{C}$ Nuclear Magnetic Resonance (NMR) techniques. ${ }^{38}$ The quality control of MSB raw material is routinely performed through a validated HPLC technique. ${ }^{39}$ Values of the different $\mathrm{pK}_{\mathrm{a}}$ 's of MF have been determined in order to assess possible chemical structures related to bioavailability and pharmacokinetics. ${ }^{40}$

The phytochemical screening of that raw material concluded that large amounts of polyphenols, terpenoids, sugars, and saponins were present in MSB and subsequent analytical work was focused on the isolation, structure characterization, and HPLC or Gas Chromatographic (GC) quantitative determinations of phenolic constituents, free sugars, and polyalcohols. ${ }^{41}$ Seven phenolic constituents, benzoic acid and its propyl ester (Figure 1), three free sugars (galactose, glucose, and arabinose), and three polyalcohols (sorbitol, myoinositol, and xylitol) were identified and quantified, this being the first report about phenolic composition of MSB.

Volatile components of MSB were extracted by Sohxlet and simultaneous steam distillation-solvent extraction (SDE), isolated and identified by GC-MS. ${ }^{42}$ The Sohxlet extract was vacuum dried in a rotary evaporator, dissolved in petroleum ether and fractionated by column preparative HPLC. Three fractions, eluted with hexane, hexane:ethyl acetate (1:1) and ethyl acetate, respectively, were obtained. Fractions were concentrated up to $1 \mathrm{~mL}$ by a KudernaDanish apparatus and thereafter analyzed. The SDE extract was used for comparative purposes. The major constituents identified were $\beta$-elemene (10), aromandrene (11), $\alpha$ guaiene (12), $\beta$-selinene (13), hinesol (14), $\beta$-eudesmol (15), $\beta$-sitosterol (16), and $\beta$-campesterol (17), (Figure 2), where the amount of sesquiterpenoid hydrocarbons was significantly higher than oxygenated compounds.

Furthermore, the composition of the fatty acid fraction was determined by GC-MS as their trimethylsilyl esters derivatives, and the major constituents were palmitic, oleic, 
<smiles>O=c1c2cc(O)c(O)cc2oc2cc(O)c([C@H]3O[C@H](CO)C[C@H]4C[C@H]3O4)c(O)c12</smiles><smiles>Oc1cc(O)c2c(c1)O[C@H](c1ccc(O)c(O)c1)[C@H](O)C2</smiles>

2<smiles>O=C(O)c1ccccc1</smiles>

4<smiles>O=C(O)c1ccc(O)c(O)c1</smiles><smiles>COC(=O)c1cc(O)c(O)c(O)c1</smiles>

8
1<smiles>Oc1cc(O)c2c(c1)O[C@H](c1ccc(O)c(O)c1)[C@H](O)C2</smiles>

3<smiles>CCCOC(=O)c1ccccc1</smiles>

5<smiles>O=C(O)c1cc(O)c(O)c(O)c1</smiles>

7<smiles>CCCOC(=O)c1cc(O)c(O)c(O)c1</smiles>

Figure 1. Chemical structures of phenolic and other related constituents of MSB, Mangiferin (1); (+) Catechin (2); (-) Epicatechin (3); Benzoic acid (4); Benzoic acid, propyl ester (5); 3,4-Dihydroxybenzoic acid (6); Gallic acid (7); Gallic acid, methyl ester (8); Gallic acid, propyl ester (9).

and linoleic, with a minor proportion of myristic and estearic acids. ${ }^{43}$ However, it was interesting to find several polyunsaturated and dicarboxylic acids of biological relevance at trace levels (eicosatrienoic, succinic, and malonic), which were quantitated by special methods. ${ }^{44}$ Between 50 and $70 \%$ of the fatty acid fraction of MSB was polyunsaturated, a possible significant contribution for the further evaluation of the antioxidant activity.

The quantitative analysis of elements in MSB of mango cultivars most commonly used for industrial processing was recently performed by Inductively Coupled Plasma Atomic Emission Spectroscopy ${ }^{45}$ Heavy metals $(\mathrm{Cd}, \mathrm{As}$, and $\mathrm{Hg}$ ) were not detected in MSB, whereas $\mathrm{Pb}$ was considerably below its toxic concentration. Significantly, the Ca content was present at recommended daily allowance (RDA) in all cultivars, and the content of all the other elements was homogeneous in 26 years old plants better than in young plants. $\mathrm{Zn}$ and $\mathrm{Cu}$ contents were below the RDA, but they were attractive, in terms of their biological significance, for all plants. The most relevant result was the consistency of Se concentration, in terms of quantity $(0.01 \mu \mathrm{g} / \mathrm{g}$ of MSB as average), and without significant differences in concentrations between cultivars $(\mathrm{p}<0.05)$.

Finally, MSB raw material was analyzed for its antioxidant capacity in terms of BHT oxidation through a gasometric technique. ${ }^{46}$ Average percentage of antioxidant components in MSB raw material was $24.1 \%$, which was considered high as compared to other natural and synthetic antioxidant substances. The overall chemical profile of the MSB raw material is shown in Table 1. Further 
<smiles>C=CC1(C)CCC(=C(C)C)C=C1C(C)C</smiles>

10<smiles>C=C(C)C1CCC2(C)CCC=C(C)C2C1</smiles>

13<smiles>C=C1CC[C@@H]2[C@@H](C(C)CCC)[C@H]1C2(C)C</smiles>

11<smiles>CC1=CCCC(C)[C@@]12CCC(C(C)(C)O)C2</smiles>

14<smiles>CC(C)=C1CC[C@H](C)C2=C(C1)[C@H](C)CC2</smiles>

12<smiles>CC[C@H](CC[C@@H](C)[C@]1(C)CC[C@H]2[C@@H]3CC=C4C[C@@H](O)CC[C@]4(C)[C@H]3CC[C@@]21C)C(C)C</smiles>

16<smiles>CC(C)[C@@H](C)CC[C@H](C)[C@H]1CC[C@H]2[C@@H]3CC=C4C[C@@H](O)CC[C@]4(C)[C@H]3CC[C@]21C</smiles>

17

Figure 2. Chemical structures of volatile components of MSB. $\beta$-Elemene (10); Aromandrene (11); $\alpha$-Guaiene (12); $\beta$-Selinene (13); Hinesol (14); $\beta$-Eudesmol (15); $\beta$-Sitosterol (16); $\beta$-Campesterol (17).

Table 1. Chemical composition of MSB raw material for nutraceutical, cosmeceutical and pharmaceutical formulations

\begin{tabular}{|c|c|}
\hline Component & Component \\
\hline 1. Polyphenols & 4.2 Galactose \\
\hline 1.1 Mangiferin & 4.3 Arabinose \\
\hline $1.2(+)$ Catechin & 5. Polyalcohols \\
\hline 1.3 (-) Epicatechin & 5.1 Sorbitol \\
\hline 1.4 Gallic acid, propyl ester & 5.2 Myoinositol \\
\hline 1.5 Gallic acid, methyl ester & 5.3 Xylitol \\
\hline 1.6 Benzoic acid, propyl ester & 6. Fatty and dicarboxylic acids \\
\hline 1.7 3,4-Dihydroxibenzoic acid & 6.1 Myristic \\
\hline 1.8 Benzoic Acid & 6.2 Palmitic \\
\hline 1.9 Gallic Acid & 6.3 Linoleic \\
\hline 1.10 Lignans & 6.4 Oleic \\
\hline 2. Terpenoids & 6.5 Estearic \\
\hline $2.1 \beta$-Elemene & 6.6 Eicosatrienoic \\
\hline 2.2 Aromandrene & 6.7 Succinic \\
\hline $2.3 \alpha$-Guaiene & 6.8 Malonic \\
\hline $2.4 \beta$-Selinene & 7. Elements \\
\hline 2.5 Hinesol & 7.1 Calcium (within RDA) \\
\hline $2.6 \beta$-Eudesmol & 7.2 Potassium \\
\hline 2.7 Cycloartanols & 7.3 Magnesium \\
\hline 3. Phytosterols & 7.4 Iron \\
\hline $3.1 \beta$-Sitosterol & 7.5 Selenium (within RDA) \\
\hline $3.2 \beta$-Campesterol & 7.6 Copper \\
\hline 4. Free sugars & 7.7 Zinc \\
\hline 4.1 Glucose & 7.8 Plumb (below toxic dose) \\
\hline
\end{tabular}

experimental work for the identification and quantitative analysis of saponins is under way at present.

\section{Antioxidant Profile of MSB Aqueous Extract}

The main antioxidant effect of the MSB is as protective agent or prophylactics against the oxidative stress due the high content of polyphenols, sesquiterpenoids, and microelements like selenium, copper and zinc. MF (1) is the major component in the whole MSB. Its chemical structure fulfill the four requisites which have been reported to have a high bioavailability by oral administration: ${ }^{47}(i)$ molecular weight below 500 dalton $\left(\mathrm{C}_{19} \mathrm{H}_{18} \mathrm{O}_{12}\right)$; (ii) less than 5 donor functions for hydrogen bonds (4); (iii) less than 10 acceptor functions for hydrogen bonds (2); (iv) potential $\log \mathrm{P}$ calculated less than $+5\left(\log \mathrm{P}_{\text {mangiferin }}:+2.73\right)$.

Other polyphenols in MSB like gallic and benzoic acid derivatives $(\mathbf{4}-\mathbf{9})$ and catechins $(\mathbf{2}, \mathbf{3})$ have similar structural properties than MF, which means that MSB polyphenols have the ability not only to protect the human organism from the attack of OCS but also to reach 
significantly target organs and tissues. The antioxidant activity of all those polyphenols is governed by the number and location of their aromatic hydroxyl groups. ${ }^{48}$ It has been suggested that the antioxidant activity of MF might be due to its ability to scavenge OCS associated to the initiation of lipid peroxidation. ${ }^{49}$

MF has been reported to have multiple biological effects. Anti-diabetic activity (type-2 diabetes) of MF (isolated from a rhizome) was tested in mice; blood glucose level was significantly decreased $(\mathrm{p}<0.01)$ after 3 weeks oral administration $(30 \mathrm{mg} / \mathrm{kg})$. However, blood glucose in normal mice was not affected indicating that MF could be useful in treating type- 2 diabetes. In addition, MF improved hyperinsulinemia, suggesting that its action may be due to the decrease of insulin resistance..$^{50} \mathrm{MF}$ (from the same rhizome) was studied on cholesterol-fed mice at the same dose; blood cholesterol and triglyceride levels were significantly reduced $(\mathrm{p}<0.05) .^{51}$

MF has also shown its potential in rat colon inducedcarcinogenesis. Malignant cell proliferation in colonic mucosa of male F344 rats was reduced by $75 \%$ after addition of MF to the diet $(0.1 \%)$ in a long-term study, which suggested that MF may act as a naturally-occurring chemopreventive agent in colon cancer. ${ }^{52}$ Chemoprevention of MF against other tumors has been also tested on ascitic fibrosarcoma (AFS) in Swiss mice. Animals received intramuscular injections with a MF solution (dose $=5 \mathrm{mg} \mathrm{MF} / \mathrm{kg}$ ) three times at an interval of $48 \mathrm{~h}$. After the last injection (48 h), AFS cultivated cells were injected $\left(10^{4}-10^{6}\right)$ and tumor growth was observed at 5 and 15 days. The inhibition of tumor growth was 47 and 36\%, respectively, as compared to the control group, and the mean survival was increased by 20 days after tumor inoculation. ${ }^{53}$

The metabolism of MF yields norathyriol after cleavage of the C-C linkage of the glucose moiety, which exhibits a potent iron chelating effect, and an inhibitory effect of the induced-respiratory burst in rat neutrophyls. ${ }^{54}$ Those effects were assumed to be originated by the high scavenger capacity of MF by singlet oxygen. However, in our experiments, as it will be described hereafter, MF did not show higher biological activity than the whole MSB raw material, and it was hypothesized that its antioxidant effect may be due to the presence of a combination of polyphenolic compounds such as catechins, galloyl, and benzoyl esters derivatives, known for their antioxidant activity, more than the single action of MF..$^{55}$

The second largest chemical group in MSB, which may contribute to its antioxidant activity, was the terpenoid family. $\beta$-Elemene (10), one of the major components in the terpenoid fraction, has exhibited anti-tumor activity on several types of leukaemia (in vitro and in vivo) by inducing the apoptosis of tumor cells..$^{56} \mathrm{~A}$ recent report ${ }^{57}$ stated that $\beta$-elemene exhibited a marked antiproliferative effect on glioma cells, and it could induce apoptosis in vitro. Hinesol (14), another main component in MSB, has inhibited $\mathrm{H}^{+}, \mathrm{K}^{+}$-ATPase by interaction with the enzyme in the E1 state, ${ }^{58}$ and such result might explain the ethnomedical observed benefitial effect on gastric disorders. Moreover, hinesol has enhanced the inhibitory effect of omeprazole on the hydrogen-pump.

$\beta$-Eudesmol (15), a third large component of this family in MSB, has been reported to modify neuronal functions by inducing neurite extension, significant increase of intracellular $\left[\mathrm{Ca}^{2+}\right]$, and promoting phosphorylation of both mytogen-activated protein kinase (MAPK), and cAMP-responsive element binding protein. ${ }^{59}$ Both, hinesol and $\beta$-eudesmol, have correlated in dose-response effect to the inhibition of the in vitro binding of $[3 \mathrm{H}]$ arginine vasopressin and $[3 \mathrm{H}]$ angiotensin II to kidney membrane receptors. ${ }^{60}$ Other major components of MSB, like $\alpha$-guaiene (12) and $\beta$-selinene (13), have similar reports in the literature ${ }^{61}$ as food or cosmetic additive, and antiparasitary against $P$. falciparum, respectively. Aromandrene (11), the last major component in MSB, has no reports of biological relevance.

$\beta$-Sitosterol (16), a MSB component of biological relevance, must be considered in terms of its nutraceutical and pharmaceutical relevance. It has been reported to reduce levels of lipemia at low concentrations and act as support of fat metabolism by reducing plasma cholesterol levels. ${ }^{62}$ It has been claimed as an essential component within a healthy diet in foods like soya and fish. Its importance on chemoprevention and chemotherapy for benign prostate hyperplasia has been also reported. ${ }^{63}$

The most significant result in the element analysis of MSB was the consistency of Se concentration for all studied mango cultivars, non-dependent from plant age. That finding might correlate with observed results on antioxidant evaluation of MSB, where the action of Se as co-factor of GP has been extensively reported. Epidemiologic studies have pointed the inverse association between nutritional Se status and cancer risk, suggesting that a relatively low Se status may be among the determinants of cancer risks. ${ }^{64}$ Experimental antitumorigenic effects of Se have been consistently associated with supranutritional levels of exposure to the element, but it is not still clear the extent that such findings depends on the form Se is administered (organic or inorganic salts). Various chemical forms of Se may vary with respect to their efficiencies of absorption and/or retention, the biochemical basis for at least some of the antitumorigenic effects of the element may reside in 
certain Se metabolites produced post-absorptively from those sources. ${ }^{65}$

$\mathrm{Cu}$ and $\mathrm{Zn}$ concentrations in MSB were significantly higher in young plants, although the concentration values in both age groups were below the RDA as dietary supplement. Therefore, plant age and cultivar were not relevant in terms of $\mathrm{Cu}$ and $\mathrm{Zn}$ concentrations. However, both elements play significant roles for the activation of SOD,${ }^{66}$ a key enzyme within the inflammatory response, and recent reports about $\mathrm{Zn}$ relevance on several physiological systems ${ }^{67}$ are attracting the attention of the medical community. Principal Component Analysis (PCA) of $\mathrm{MSB}^{45}$ showed four different groups of mango cultivars regarding its element composition The first and main group of cultivars was predominantly correlated by $\mathrm{Ca}, \mathrm{K}$, and $\mathrm{Cu}$, while the second large group was correlated by $\mathrm{Ca}$. However, those observations must be carefully considered since the Se concentration was not included in PCA analysis, with a presumable higher contribution to the antioxidant effect of MSB than $\mathrm{Ca}, \mathrm{K}$, and $\mathrm{Cu}$.

In vitro and in vivo antioxidant evaluation of MSB raw material have been reported recently ${ }^{68}$ and a summary of those results are shown in Table 2. The concentrations at which MSB exhibits its antioxidant effects in terms of lipid peroxidation inhibition, protection from the oxidative damage, and scavenger capacity of OCS, are extremely low. Highly significant was the liver- and brain-protecting effect from in vivo experiments on rats and gerbils, respectively, in ischaemia-reperfusion models at doses of $50 \mathrm{mg} / \mathrm{kg}$ b. w. A potent inhibition of lipid peroxidation on low-density lipoproteins was also found in vivo (atherogenic rats). ${ }^{69}$

MSB was tested against vitamins $(\mathrm{C}, \mathrm{E}$, and $\mathrm{C}+\mathrm{E})$ and

Table 2. Antioxidant profile of MSB raw material for nutraceutical, cosmeceutical and pharmaceutical formulations

\begin{tabular}{lc}
\hline Antioxidant test & $\mathrm{IC}_{50}(\% \mathrm{~m} / \mathrm{v})$ \\
\hline Scavenging of hypochlorous acid & 0.04 \\
Scavenging of hydroxyl radical & 0.01 \\
Chelating effect on iron & 0.12 \\
Antioxidant effect on DNA & $0.01-0.02$ \\
Pro-oxidant effect on DNA (up to $5 \mathrm{~g} / \mathrm{kg}$ b.w.) & $\mathrm{NONE}$ \\
Spontaneous lipid peroxidation inhibition (LPI) & 0.21 \\
Catalyzed LPI by iron & 0.01 \\
Microsomal LPI (MLPI) & 0.00075 \\
Catalyzed MPLI by iron & 0.01 \\
Protection to DNA (attack to sulfur bridges bet & 0.006 \\
ween protein chains) & \\
Protection to DNA (attack to the peptide bonds & 0.005 \\
in protein chains) & \\
Inhibition of damage induced by hepatic & $110 \mathrm{mg} / \mathrm{kg}$ oral \\
ischaemia/reperfusion (rats) & \\
Inhibition of damage induced by brain & $50 \mathrm{mg} / \mathrm{kg}$ oral \\
ischaemia/reperfusion (Gerbils) & \\
\hline
\end{tabular}

$\beta$-carotene in vivo (rats) in terms of lipid peroxidation inhibition (LPI), and protection from oxidative damage (POD).$^{70}$ LPI values for MSB were similar to those of vitamins in plasma, significantly higher than vitamin $\mathrm{C}$ and $\beta$-carotene in liver, and similar to the combination of vitamins $\mathrm{C}+\mathrm{E}$ in brain. POD values for MSB were significantly higher than those for all products tested in plasma, macrophages, liver, and brain, being the most significant in brain. It was concluded that MSB could be useful to prevent the overproduction of OCS and oxidative damage in vivo, and it was more active than vitamin $\mathrm{C}$, vitamin $\mathrm{E}, \mathrm{MF}$, and $\beta$-carotene.

\section{Pharmacological Profile of MSB Aqueous Extract}

Ethnomedical reports of MSB in several countries in Africa and Central America have described its use as antiinflammatory ${ }^{71}$ and analgesic. ${ }^{72}$ There are several evidences about the correlation between the oxidative damage at tissue and cell levels and the response to pain and inflammation. The attack of OCS to cartilage and muscle tissues may initiate lipid peroxidation, inactivate membrane sodium channels, and modify proteins related to cytokine expression. All these events are likely to play a role in the pathophysiology of shock, inflammation, and ischaemia/reperfusion. Antioxidant therapy, i.e., inhibits the activation of poly (ADP-ribose) synthetase and prevents tissue injury associated with shock and inflammation. ${ }^{73}$ Cytokines promote new OCS from the activation of other transcriptional factors like the nuclear factor $\kappa \mathrm{B} .{ }^{74}$

The correlation oxidative stress-inflammatory response lead us to test the anti-inflammatory and analgesic effects of MSB in order to determine its possible therapeutical uses against pain and inflammation, and explain the observed improvement of patients in terms of their quality of life. Experimental results have been extensively reported ${ }^{75}$ and may be summarized as follows: $(i)$ reduction of the induced-inflammation by carragenane in rats as acute inflammation models by $39.5 \%$ (rats), $45.0 \%$ (Guineapigs), and $46.8 \%$ (mice) with a dose-response effect; (ii) reduction of the induced-pain by formalin and acetic acid with $\mathrm{ED}_{50}$ (medium effective dose) values of 8.4 and 54.5 $\mathrm{mg} / \mathrm{kg}$ b.w., respectively, with a dose-response effect; (iii) inhibition of $\beta$-glucuronidase in a chronic rheumatoid arthritis model induced by zymosan with $\mathrm{IC}_{50}$ (inhibitory concentration) $=44.5 \mathrm{mg} / \mathrm{kg}$ b.w. (rats). MSB inhibited cartilage and connective tissue degradation due to the attack of OCS; (iv) inhibition of chemotaxis by nuclear polymorphs (ICAM-1), which are related to the activation of the vascular endothelium and the transmigration of 
leukocytes to the inflammated tissue; $(v)$ inhibition of the production of prostaglandin $\mathrm{E}_{2}$ (PGE 2) and leukotrienes $\mathrm{B}_{4}$ (LTB 4) with $\mathrm{IC}_{50}$ values of 64.1 and $22.9 \mu \mathrm{g} / \mathrm{mL}$, respectively; ( $v i$ ) inhibition of phospholypase $\mathrm{A}_{2}$ (PLA 2) in sinovial secretions $\left(\mathrm{IC}_{50}=0.7 \mu \mathrm{g} / \mathrm{mL}\right.$ ); (vii) inhibition of the production of tumor necrosis factor $\left(\mathrm{TNF}_{\alpha}\right)$ in activated macrophages by a septic shock, and microgial cells (RAW 264.7) with $\mathrm{IC}_{50}$ values of 159.2 and $63.6 \mu \mathrm{g} /$ $\mathrm{mL}$, respectively. $\mathrm{ED}_{50}$ from a in vivo model with mice, where the septic shock was induced by lipopolysaccharide, was $64.5 \mathrm{mg} / \mathrm{kg}$ b.w.; (viii) inhibition of the nuclear transcriptional factor $\kappa \mathrm{B}\left(\mathrm{IC}_{50}=0.75 \mu \mathrm{g} / \mathrm{mL}\right) ;(i x)$ inhibition of the production of nitric oxide in activated macrophages $\left(\mathrm{IC}_{50}=69.4 \mu \mathrm{g} / \mathrm{mL}\right)$ and reduction of $1 \beta$ interleukyne expression; $(x)$ inhibition of cyclooxigenase 2 (COX 2), $\mathrm{IC}_{50}=0.5 \mu \mathrm{g} / \mathrm{mL}$.

MSB has also modulated several immune responses. It has a mytogenic effect on lymphoid populations ${ }^{76}$ with high stimuli on the prolipheration of $\mathrm{T}$ lymphocytes. A lack of Se in plasma has been reported to inhibit SOD, GP, and GR, which depresses the immunological response. ${ }^{77}$ Other experiments demonstrated that MSB inhibited immunoglobulines G (specifically $\operatorname{IgG} 2 \mathrm{a}$ and $\operatorname{IgG} 2 \mathrm{~b}$ ), typical of a T helper 1 (Th1) cells macrophage activation, without affecting the production of $\operatorname{IgM} .^{78}$ Furthermore, MSB inhibited the production of specific $\operatorname{IgE}$ and the cutaneous anaphylaxis response, probably by a mechanism where the mastocyte membrane was stabilized. ${ }^{79}$

Relevant clinical trials with pharmaceutical formulations of MSB raw material (Vimang) have been done on HIV/AIDS, geriatrics, and as anti-inflammatory and analgesic in Primary Health Care on 642 patients. ${ }^{80}$ HIV/AIDS patients (seropositive with CD4 counts between 300 and 500) were administered with 8 Vimang tablets/ day (300 mg MSB) before meals for six months in a doubleblind randomised trial (36 patients Vimang; 32 patients placebo). Seven of nine oxidative stress biomarkers were improved in 58\% of the Vimang group, against 3\% of the placebo group, both diet-controlled.. The Vimang group reached the same value of plasma biomarkers as the seronegative control group. Statistical trends were observed for the improvement of CD4 and CD95 counts, and the reduction of transaminase, uric acid, and erythrosedimentation in the Vimang group, and no toxic effects, nor side effects, were found for the Vimang group in plasma, kidney, and liver. A second trial, with a larger amount of patients and 12-months duration, is going at present.

A group of 31 adults older than 65 years were administered daily with 3 Vimang tablets before meals for
2 months in a pilot controlled trial in Primary Health Care, in order to measure the improvement on their quality of life. Eight of nine evaluated parameters were improved at the end of the trial, but the most significant was "body pain", which started to improve significantly after 15 days of the initial treatment. A second study in Primary Health Care was organized with the Vimang cream formulation $(1.2 \%)$, in order to assess its effectiveness on inflammation and pain in several pathological disorders, mainly on skin. $86.8 \%$ and $96.7 \%$ of all patients (490) were improved in terms of inflammation and pain, respectively, in times ranging from 7 to 90 days (2 daily applications) depending on the skin disorder or pain location.

\section{Conclusions}

Chemical, pre-clinical, and clinical results with the use of MSB raw material in nutraceutical, cosmeceutical and phytopharmaceutical formulations (Vimang) is a reality for its use as an antioxidant product with a high therapeutical potential on diseases related to oxidative stress, and which may contribute to extend the use of antioxidant products by physicians, together with the specific standard therapies, in a large number of diseases. Its efficacy as prophylactics would be proved in long term and large population studies.

\section{Acknowledgements}

Financial support from the Ministry of Science, Technology and Environment (CITMA) and the Ministry of Public Health (MINSAP), Republic of Cuba, is gratefully acknowledged. Thanks to J. Fernández Bertrán for reviewing the manuscript, Rosemary Rebollo for the English revision and to J. A. Ruiz García for the figures.

\section{References}

1. Reanaud, S.; De Lorgeril, M.; Lancet 1992, 339, 1523.

2. Dembow, H. S.; Slane, P. R.; Folts, J. D.; Circulation 1994, 91 , 1182 .

3. Jovanovic, S.V.; Steenken, S.; Tosic, M.; Marjanovic, B.; Simic, M. G.; J. Am. Chem. Soc. 1994, 116, 4686.

4. Frankel, E. N.; Kanner, J.; German, J. B.; Parks, E.; Kinsella, J. E.; Lancet 1993, 341, 454.

5. Fuhrman, B.; Lavi, A.; Aviram, M.; Am. J. Clin. Nutr. 1995, $61,549$.

6. Cutler, R. G.; Am. J. Clin. Nutr. 1991, 53, 373S.

7. Pitot, H. C.; Dragan,Y. P.; FASEB J. 1996, 5, 2280.

8. Kehrer, J. P.; Crit. Rev. Toxicol. 1993, 23, 21.

9. Halliwel, B.; Free Rad. Res. 1996, 25, 57. 
10. Hertog, M. G.; Kromhout, D.; Aravanis, C.; Blackburn, H.; Ruzina, B.; Fidanza, F.; Giampaoli, S.; Jansen, A.; Menotti, A.; Nedeljkovic, S.; Arch. Internat. Med. 1995, 155, 381.

11. Burr, M. L.; J. Human Nutr. Dietet. 1994, 7, 409.

12. Miller, N. J.; Jonston, J. D.; Collis, C. S.; Rice-Evans, C.; Ann. Clin. Biochem. 1997, 34, 85.

13. O’Brien, S. F.; Watts, G. F.; Powrie, J. K.; Shaw, K. M.; Millar, N. J.; Diabetes Res. Clin. Pract. 1996, 32, 81

14. Heliovarra, M.; Knekt, P.; Aho, K.; Aaran, R. K.; Alfthan, G.; Aromaa, A.; Ann. Rheum. Dis. 1994, 53, 51.

15. Sharma, R. K.; Agarwal, A.; Urology 1996, 48, 835.

16. Ebadi, M.; Srinivasan, S. K.; Baxi, M. D.; Progr. Neurobiol. 1996, 48,1

17. Portal, B. C.; Richard, M. J.; Faure, H. S.; Hadjian, A. J.; Favier, A. E.; Am. J. Clin. Nutr. 1995, 61, 843.

18. Kelly, F.; Abstracts of the $2^{\text {nd }}$ International Meeting "Free Radicals in Health and Disease”, Istanbul, Turkey, 2002.

19. Levin, B.; Health Nutr. Breakthr. 1998, 2, 130.

20. Tapadinhas, M. J.; Rivera, I. C.; Bignamini A. A.; Pharmather. 1982, 3, 157.

21. Manzella, D.; Barbieri, M.; Ragno, E.; Paolisso, G.; Am. J. Clin. Nutr. 2001, 73, 1052.

22. Vertugno, M.; Maino, A.; Cardia, G.; Quarante, G.M.; Cardia, L.; Br. J. Ophtalmol. 2001, 85, 573.

23. Napralert Database; University of Illinois, Chicago, IL. http://www. ag.uiuc.edu/ffh/napra.html, accessed at Sept. 25, 2002.

24. Guevara García, M.; Tamayo Méndez, D.; González Laime, S.; Núñez Sellés, A. J.; Rev. Cub. Farm. 2000, 14, 68; Guevara García, M.; Riaño Montalvo, A.; Alvarez León, A.; Garrido Garrido, G.; Paéz Betancourt, E.; Rev. Cub. Farm. 2002, 36 , 166.

25. Tamayo Méndez, D.; Mari, E.; González Laime, S.; Guevara García, M.; Garrido Garrido, G.; Delgado Hernández, R.; Marchioli, R.; Núñez Sellés, A. J.; Minerva Medica 2001, 92, 95.

26. Núñez Sellés, A. J.; Capote Hernández, R.; Agüero Agüero, J.; Garrido Garrido, G.; Delgado Hernández, R.; Martínez Sánchez, G.; León Fernández, O. S.; Morales Segura, M. A. Abstracts of the $220^{\text {th }}$ Annual Meeting of the American Chemical Society, Washington D. C., USA, 2000.

27. Núñez Sellés, A. J.; Paéz Betancourt, E.; Amaro González, D.; Acosta Esquijarosa, J.; Agüero Agüero, J.; Capote Hernández, R.; Gárciga Hernández, M. R.; Morales Lacarrere, I.; García Pulpeiro, O.; Garrido Garrido, G.; Martínez Sánchez, G.; Morales Segura, M. A.; CU Patent No. 22846, 2002.

28. Martínez Sánchez, G.; Delgado Hernández, R.; Garrido Garrido, G.; Guevara Garcia, M.; García Rivera, D.; Paéz Betancourt, E.; Núñez Sellés, A. J.; Mitos y Realidades de la Terapia Antioxidante. Vimang: Nuevo Producto Natural Antioxidante, Center of Pharmaceutical Chemistry: Havana, 2003.
29. Gey, K. F. In Free Radicals in the Environment, Medicine and Toxicology; Cody, B.; Middleton, E.; Harborne, J. B., eds., A.R. Liss: New York, 1994, p. 15.

30. Cutter, R. C.; Rodríguez, H.; eds.; Critical Reviews of Oxidative Stress and Aging, World Scientific: London, 2002.

31. Sayre, M.; Smith, A.; Perry, G.; Curr. Med. Chem. 2001, 8, 721.

32. Schulz, J. B.; Lindenau, J.; Seyfried, J.; Dichgans, J.; Eur. J. Biochem. 2000, 267, 4904; Sano, M.; Ernesto, C.; Thomas, R. G.; Klauber, M. R.; Schafer, K.; Grundman, M.; Woodbury, P.; Growdon, J.; Cotman, C. W.; Pfeiffer, E.; Schneider, L. S.; Thal, L. J.; N. Engl. J. Med. 1997, 336, 1216.

33. Domenico, P.; Clark, C. M.; Liun, F.; Lee, V.Y.; Trojanowski, J. Q.; Arch. Neurobiol. 2002, 59, 972; Lovell, M. A.; Ehman, W. D.; Butler, S. M.; Markesbery, W. R.; Neurology 1995, 45, 1594; Marcus, D. L.; Thomas, C.; Rodríguez, C.; Simberkoff, K.; Tsai, J. S.; Strafaci, J. A.; Freedman, M. L.; Exp. Neurol. 1998, 150, 40.

34. Klein, J. A.; Longo, C. M.; Rossman, M. P.; Seburn, L.; Hurd, R. E.; Frankel, W. N.; Bronson, R.T; Ackerman, S. L.; Nature 2002, 419, 668.

35. Morel, Y.; Barouki, R.; Biochem. J. 1999, 42, 48.

36. González, J. C.; Centro de Química Farmacéutica, Documento Confidencial, 04/00/3.10.00, 1998.

37. Guardado, I.; Sordo, L.; Vidal, M. C.; Amaro, D.; González, I.; Centro de Química Farmacéutica, Informe Técnico, CQF-006005-003-1, 1997.

38. Capote, R.; Govaerst, C.; González, Y.; Núñez Sellés, A. J.; Van Schepdael, A.; Roets, E.; Hoogmartens, J.; Rev. Cub. Quim. 2001, 13, 374.

39. González Hernández, R.; Capote Hernández, R.; Nuevas Paz, L.; González Merlo, Y.; Vélez Castro, H.; Núñez Sellés, A. J.; Rev. Cub. Quim. 2001, 13, 373.

40. Núñez Sellés, A. J.; Delgado, R.; Berenice, O.; Pérez, T.; González Vergara, E.; Centro de Química Farmacêutica, Informe Técnico CQF.88.133.091, 2004.

41. Núñez Sellés, A .J.: Vélez Castro, H. T.; Agüero Agüero, J.; González González, J.; Naddeo, F.; De Simone, F.; Rastrelli, L.; J. Agric. Food Chem. 2002, 50, 762.

42. Lora García, J.; Durruthy Rodríguez, M. D.; Núñez Sellés, A. J.; Food Chem., submitted.

43. Lora García, J.; Agüero Agüero, J.; Concepción Martínez, F.; Núñez Sellés, A. J.; Rev. Cub. Quim. 1998, 10, 272.

44. González, L.; Marrero, D.; González, J. L.; J. Chromatogr. 2000, 888, 159.

45. Núñez Sellés, A. J.; Durruthy Rodríguez, M. D.; J. Agric. Food Chem., submitted.

46. Sordo Martínez, L.; Reinosa Espinosa, O.; Rev. CENIC Ciencias Quim. 2003, 34, 238.

47. Lipinski, C. A.; Lombardo, F.; Dominy, B. W.; Feeney, P. J.; Adv. Drug Deliv. Rev. 1997, 23, 3.

48. Chen, Z. Y.; Chan, P. T.; Ho, K. Y.; Fung, K. P.; Wang, J.; Chem. Phys. Lipids 1996, 79, 157. 
49. Sato, T.; Kawamoto, A.; Tamura, S.; Tatsum, Y.; Fujii, T.; Chem. Pharm. Bull. 1992, 40, 721.

50. Miura, T.; Ichiki, H.; Hashimoto, I.; Iwamoto, N.; Kato, M.; Kubo, M.; Ishihara, E.; Komatsu, Y.; Okada, M.; Ishida, T.; Tanigawa, K.; Phytomedicine 2001, 8, 85.

51. Miura, T.; Iwamoto, N.; Kato, M.; Ichiki, H.; Kubo, M.; Komatsu, Y.; Ishida, T.; Okada, M.; Tanigawa, K.; Biol. Pharm. Bull. 2001, 24, 1091.

52. Yoshimi, N.; Matsunaga, K.; Katayama, M.; Yamada, Y.; Kuno, T.; Qiao, Z.; Hara, A.; Yamahara, J.; Mori, H.; Cancer Lett. 2001, 163, 163.

53. Guha, S.; Ghosal, S.; Chattopadhyav, V.; Chemotherapy (Basel) 1996, $42,443$.

54. Hsu, M. F.; Raung, S. L.; Tsao, L. T.; Lin, C. N.; Wang, J. P.; Free Rad. Biol. Med. 1997, 23, 1035; Pardo Andreu G.; Delgado R.; Velho J. A.; Curti C.; Vercesi A.E.; Eur. J. Pharmacol. 2005, 513, 47; Pardo Andreu G.; Delgado R.; Velho J. A.; Inada N. M.; Curti C.; Vercesi A. E.; Pharmacol. Res. 2005, $51,427$.

55. Arts, I. C. W.; Van de Putte, B.; Hollman, P.; J. Agric. Food Chem. 2000, 48, 1746; Lin, J. K.; Chen, P. C.; Ho, C. T.; LinShiau, S. Y.; J. Agric. Food Chem. 2000, 48, 2736.

56. Zheng, S.; Yang, H.; Wang, X.; Yu, L.; Lu, J.; Li, J.; J. Cell Biol. Suppl. 1997, 27, 106.

57. Zhou, H. Y.; Shen, J. K.; Hou, J. S.; Qiu, Y. M.; Luo, Q. Z.; $A i$ Zheng 2003, 22, 959.

58. Satoh, K.; Nagai, F.; Kano, I.; Biochem. Pharmacol. 2000, 59, 881.

59. Obara,Y.; Aoki,T.; Kusano, M.; Ohizumi, Y.; Pharmacol. Experim. Therap. 2002, 301, 803.

60. Takeda, O.; Tsuchiya, K.; Kimura, K.; Kubo, M.; Okada, M.; He, S.A.; Pharmac. Biol. 2001, 39, 191.

61. Emin Duru, M.; Cakir, A.; Harmandar, M.; Izumi, S.; Hirata, T. ; Flavour Frag. J. 1999,14, 12 ; Planchart, A.; Núñez, C. V.; Franca, N.; Kimura, E. A.; Katzin, A. M.; Mem. Inst. Oswaldo Cruz 1997, 92, 512.

62. Jones, P. J.; Raeini-Sarjaz, M.; Ntanios, F. Y.; J. Lipid Res. 2000, 41, 697.

63. Klippel, K. F.; Hitl, D. M.; Schipp, B. A.; Br. J. Urol. 1997, 80, 427.

64. Yu, S. Y.; Chu, Y. J.; Gong, X. L.; Hou, C.; Li, W. G.; Gong, H. M.; Xie, J. R.; Biol. Trace Elem. Res. 1985, 7, 21; Clark, L. C.; Combs, G. F.; Hixon, L.; Deal, D. R.; Moore, J.; Rice, J. S.; Dellasega, M.; Rogers, A.; Woodward, J.; Schurman, B.; Curtis, D.; Turnbull, B. W.; FASEB J. 1993, 7, A65; Clark, L.; Hixon, L.; Combs, G. F.; Reid, M.; Turnbull, B. W.; Sampliner, R.; Cancer Epidemiol. Biomarkers Prev. 1993, 2, 41; Combs, G. F. In Antioxidants and Disease Prevention; Garewal, H. ed., CRC Press: New York, 1997, p. 97; Schulz, J. B.; Lindenau, J.; Seyfried, J.; Dichgans, J.; Eur. J. Biochem. 2000, 267, 4904
65. Deagan, J.; Butler, J.; Zachara, B.; Whanger, P.; Anal. Biochem. 1993, 208, 176; Ip, C.; El-Bayoumy, K.; Upadhyaya, P.; Ganther, H.; Vadanavikit, S.; Thompson, H.; Carcinogenesis 1994, 15, 187; Salonen, J. T.; Raung, L. T.; Miller, G.; Brit. Med. J. 1995, 290, 417; Stadtman, T. C.; Annu. Rev. Biochem. 1996, 65, 83; Combs, C. F.; Gray, W. P.; Pharmacol. Ther. 1998, 79, 179.

66. Jobe, A. H.; Pediatrics 2003, 111, 680; Salvemini, D.; Cuzzocrea, S.; Crit. Care Med. 2003, 31, 29.

67. Valee, B. L.; Falchuk, K. H.; Physiol. Rev. 1993, 73, 79; Prasad, A.S.; J. Am. Coll. Nutr. 1996, 15, 113.

68. Martinez Sánchez, G.; Delgado Hernández, R.; Pérez Davidson, G.; Garrido Garrido, G.; Núñez Sellés, A. J.; León Fernández, O. S.; Phytother. Res. 2000, 14, 424; Martínez Sánchez, G.; Candelario Jalil, E.; Giuliani, A.; León Fernández, O. S.; Ram, S.; Delgado Hernández, R.; Núñez Sellés, A. J.; Free Rad. Res. 2000, 32, 1; Martínez Sánchez, G.; Giuliani, A.; León Fernández, O.S.; Pérez Davidson, G.; Núñez Sellés, A. J.; Phytother. Res. 2001, 15, 581.

69. Loy, S.; Simón, R.; Delgado Hernández, R.; Rev Cub. Invest. Biomed 2002, 21, 167.

70. Martínez Sánchez, G.; Re, L.; Giuliani, A.; Núñez Sellés, A. J.; Pérez Davidson, G.; León Fernández, O. S.; Pharmacol. Res. 2000, 42, 565 .

71. Singh, Y. N.; J. Ethnopharmacol. 1986, 15, 57; Chhabra, S. C.; Mahunnah, R. L. A.; Mshhiu, E. N.; J. Ethnopharmacol. 1987, 21, 253; Darias, V.; Bravo, L.; Rabana, R.; Sánchez Mateo, C.; González Luis, R. M.; Hernández Pérez, A. M.; J. Ethnopharmacol. 1989, 25, 77; Awe, S.O.; Olajide, O.A.; Oladidrn, O. O.; Makinde, J. M.; Phytother. Res. 1998, 12, 437.

72. Le Grand, A.; J. Ethnopharmacol. 1989, 25, 315; Muanza, D. N.; Kim, B. W.; Euler, K. L.; Williams, L.; Internat J. Pharmacol. 1994, 32, 337; Coe, F. G.; Anderson, J.; J. Ethnopharmacol. 1996, 53, 29.

73. Kyriakis, J. M.; Avruch, J.; Bioassays 1996, 18, 567; Cuzzocrea, S.; Riley, D. P.; Caputi, P. A.; Salvemini, D.; Pharmacol. Rev. 2001, 53, 135.

74. Karin, M.; Neriah, B.; Ann. Rev. Immunol. 2000, 18, 621; Li, Q.; Verma, M. I.; Nature Rev. 2002, 2, 725.

75. Garrido, G.; González, D.; Delporte, C.; Backhouse, N.; Quintero, G.; Núñez Sellés, A. J.; Morales, M. A.; Phytother. Res. 2001, 15, 18; Delgado, R.; Garrido, G.; González, D.; Herrera, B.; Beltrán, A.; Lemus, Y.; Rodríguez, J.; Quintero, G.; Lodeiro, L.; Tamayo, D.; Sironi, M.; Ledón, N.; Romay, C.; García, D.; Núñez Sellés, A. J.; Minerva Medica 2001, 92, 98; Beltrán, A.; Ledón, N.; Romay, C.; Sironi, M.; Quintero, G.; Delgado, R.; Garrido G.; Rev. Cub. Investig. Biomed. 2003, 22, 164. Garrido, G.; González, D.; Lemus, Y.; García, D.; Lodeiro, L.; Quintero, G.; Delporte, C.; Delgado, R.; Núñez Sellés, A. J.; Pharmacol. Res. 2004, 50, 143; Garrido, G.; Delgado, R.; Lemus, Y.; Rodríguez, J.; García, D.; 
Núñez Sellés, A. J.; Pharmacol. Res. 2004, 50, 165; Beltrán, A.

E.; Alvarez, Y.; Xavier, F. E.; Hernanz, R.; Rodríguez, J.; Núñez Sellés, A. J.; Alonso, M. J.; Salaices, M.; Eur. J. Pharmacol. 2004, 499, 297.

76. Delgado, R.; Centro de Química Farmacéutica, Informe Técnico, CQF.99.030.001, 1999; Del Valle Pérez, L.; Socarrás Ferrer, B. B.; Torres Leyva, I.; Marsán Suárez, V.; Macías Abraham, C.; Hernández Ramírez, P.; Ballester Santovenia, J. M.; Rev. Cub. Hematol. Inmunol. Hemoter. 2003, 19, 1.

77. Baiaer Bitterlich, G.; Funchs, D.; Wachter, H.; Biochem.. Pharmacol. 1997, 53, 755.

78. García, D.; Leiro, J.; Delgado, R.; San Martín, M. L.; Ubeira, F. M.; Phytother. Res. 2003, 17, 1182.

79. García, D.; Escalante, M.; Delgado, R.; Ubeira, F. M.; Leiro,
J.; Phytother. Res. 2003, 17, 1203.

80. Gil, L.; Martínez, G.; González, I.; Tarinas, A.; Alvarez, A.; Molina, R.; Robaina, M.; Tápanes, R.; Pérez, J.; Guevara, M.; Núñez Sellés, A. J.; León, O. S.; Free Rad. Res. 2002, 36, 107; Díaz de la Rocha, A.; Rodríguez Lara, L.; Santano, López, J. L.; Bravo Hernández, A.; Iglesias Dios, J. L.; Tamayo Benítez, D.; González Laime, S.; Guevara García, M.; Núñez Sellés, A. J.; Centro de Quimica Farmaceutica, Informe Técnico, CQF.00.022.005, 2000; Cruz, R.; Guevara García, M.; Garrido Garrido, G.; Núñez Sellés, A. J.; Centro de Quimica Farmaceutica, Informe Técnico, CQF.00.057.013, 2000.

Received: July 30, 2004 Published on the web: June 17, 2005 